GOD AND THE UNIVERSE OF FAITHS 
By the same author

FAITH AND KNOWLEDGE

Evil AND The God of Love

ARgumENTS FOR THE EXISTENCE OF GOD

Death and Eternal Life

God has Many Names

Faith and the Philosophers (editor)

The Many-Faced Argument (editor with A. C. McGill)

Philosophy of Religion

The Second Ghristianity

Why Believe in God? (with Michael Goulder)

The Existence of God (editor)

Classical and Contemporary Readings in the Philosophy

of RELigion (editor)

Truth and Dialogue (editor)

The MYth of God Incarnate (editor)

Christianity and Other Religions

(editor with Brian Hebblethwaite)

Problems of Religious Pluralism 


\title{
GOD AND THE UNIVERSE OF FAITHS
}

Essays in the Philosophy of Religion

\author{
John Hick
}

Danforth Professor of the Philosophy of Religion

The Claremont Graduate School, California

REISSUED WITH A NEW PREFACE

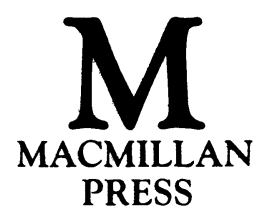


(C) John Hick 1973, 1977, 1988

Softcover reprint of the hardcover 1st edition 1988 978-0-333-41784-3

All rights reserved. No reproduction, copy or transmission of this publication may be made without written permission.

No paragraph of this publication may be reproduced, copied or transmitted save with written permission or in accordance with the provisions of the Copyright Act 1956 (as amended).

Any person who does any unauthorised act in relation to this publication may be liable to criminal prosecution and civil claims for damages.

First edition (Macmillan and St Martin's Press) 1973

First paperback edition (Fount) 1977

Reissued with a new preface (Macmillan) 1988

Published by

THE MACMILLAN PRESS LTD

Houndmills, Basingstoke, Hampshire RG21 2XS

and London

Companies and representatives throughout the world

British Library Cataloguing in Publication Data

Hick, John

God and the universe of faiths : essays

in the philosophy of religion.- Rev.

1. Religion-Philosophy

I. Title

$200^{\prime} .1$

BL51

ISBN 978-0-333-41785-0

DOI 10.1007/978-1-349-19049-2 


\section{Contents}

Preface to the 1988 Reissue vii

Preface to the First Edition ix

Acknowledgements $\quad \mathrm{xv}$

Introduction xvii

I Theology's Central Problem I

2 Religion as Fact-asserting 18

3 Religious Faith as Experiencing-as 37

4 God, Evil and Mystery 53

5 The Problem of Evil in the First and Last Things 62

6 God as Necessary Being 75

7 The Reconstruction of Christian Belief 92

8 The Essence of Christianity 108

9 The Copernican Revolution in Theology 20

Io The New Map of the Universe of Faiths I 33

I I Christ and Incarnation 148

12 Incarnation and Mythology 165

I 3 Towards a Theology of Death 180

$\begin{array}{ll}\text { Index } & \mathbf{I} 99\end{array}$ 


\section{Preface to the 1988 Reissue}

WHEN THIS book was first published the problem of the relation between Christianity and other religions was looming up over the horizon of Christian consciousness in the west. It had already been discussed for fifty years or more by a small minority of scholars but had as yet hardly affected the main stream of Christian thinking. During the last decade or so however the problem has risen towards the top of the theological agenda. It is now common to distinguish three main responses: exclusivism (salvation is exclusive to Christians), inclusivism (Christian salvation is extended in principle to all people, whether Christian or not), and pluralism (the great world faiths, including Christianity, are different and independently authentic spheres of revelation and salvation). Most responsible Christian thinking, as expressed by Vatican II and the World Council of Churches, has now moved from exclusivism to inclusivism. This book urges the case for a further 'paradigm shift' from inclusivism to pluralism.

Various issues are involved. Logically, inclusivism seems an instable interim position and the further move to a frankly acknowledged pluralism seems almost inevitable. For once we have accepted that salvation is not restricted within the borders of Christianity but that Jews are being saved within and through the spiritual structures of Judaism, Muslims within and through those of Islam, Buddhists within and through those of the Buddhist dharma, Sikhs within and through those of the Sikh tradition, Hindus within and through those of the multifarious forms of Indian religious life, and so on, why should we affix a Christian label upon all these different spheres of salvation? Why not simply accept that the transformation of human existence from self-centeredness to a new centering in the Ultimate Reality which we call God, is taking place in and through all the great world traditions, of which Christianity is one? This seems to be the natural conclusion to be 
drawn once the old exclusivist dogma has been abandoned.

But on the other hand the move to a pluralist affirmation of the other world religions involves a re-understanding of such central Christian ideas as Incarnation, Trinity and Atonement. The traditional incarnational doctrine, holding that Jesus was God the Son, the Second Person of a divine Trinity, living a human life, by implication singles out Chrisitianity as the one religion founded by God in person, with the only full knowledge of God and the only true gospel of God's saving activity. Is it however possible to understand the undoubted positive fact of divine presence and power in the life of Jesus without those unacceptably imperialistic implications? My own answer, expressed in some of the later chapters of this book, is that a Christian self-understanding compatible with religious pluralism is entirely possible, and that it lies within the range of the natural development of Christian thought.

The many-sided debate about all this that has been taking place in Christian circles during the last fifteen or so years is well summarized and analyzed in two recent books, one by an Anglican and the other by a Roman Catholic author: Alan Race's Christians and Religious Pluralism (SCM Press: London, 1983 and Orbis Books: New York, 1983) and Paul Knitter's No Other Name? (SCM Press: London, 1985 and Orbis Books: New York, 1985). I hope that the present reissue of God and the Universe of Faiths may help to stimulate yet further a debate that is critically important for the relationship between Christian and the non-Christian majority of the human race.

I must add that it has not been possible, for reasons of cost, to recast this book in inclusive language, avoiding for example the use of 'man' and 'he' when referring to human beings in general. It is in fact as inappropriate to write of the human race as though it were exclusively male as to write of religion as though it were exclusively Christian! But these chapters were written before I had become conscious of this now obvious fact.

Department of Religion

Claremont Graduate School

Claremont, California 91711

JoHn Hick 


\section{Preface to the First Edition}

This book deals with issues which are both old and new. Half of it is about some of the long-standing fundamental problems of religion: the nature of faith, the problem of evil, the idea of God, the religious understanding of death. For if one holds, as I do, that the core of religious language is factual in character, so that it professes to indicate something of the actual structure of reality, then all of these questions unavoidably arise. One has to uphold the cognitive, or fact-asserting, nature of God-language against the various non-cognitivist analyses of it which are popular today (chapters 1 and 2). One has to show how religious faith, so far from being an arbitrary projection of our desires, may be a proper response to the deeper ambiguities of human existence (chapter 3). One has to face the challenge posed by suffering and wickedness to belief in a loving creator (chapters 4 and 5). One has to consider whether the concept of God is coherent and illuminating (chapter 6). And one has to relate all this to the universal fact of our mortality (chapter 13). These topics belong to the perennial repertoire of the philosophy of religion, though appearing today in the new context of our modern concern with the philosophy of language.

The other half of the book concerns a problem which is in principle as old as the others but which has in fact only become apparent and pressing during the last fifty years or so. This is the problem of the relation between the different religions of the world, a topic which has been looming ever larger on the horizon of religious thought as the adherents of each of the world faiths have become more clearly aware of the spiritual reality of the other faiths. From my own personal point of view these chapters repre- 
sent a fairly considerable process of rethinking in response to new experiences. The whole subject of the relation between Christianity and the other religions is one which I had, in effect, largely ignored until coming to live ten years ago in the multi-cultural, multi-coloured, and multi-faith city of Birmingham and being drawn into some of the practical problems of religious pluralism. I now no longer find it possible to proceed as a christian theologian as though Christianity were the only religion in the world. Surely our thinking must be undertaken, in the 'one world' of today and tomorrow, on a more open and global basis. Accordingly chapters 8, 9 and 10 seek to develop a christian theology of religions which takes the decisive step from what I call a Ptolemaic (i.e. one's-own-religion-centred) to a Copernican (i.e. a God-centred) view of the religious life of mankind.

In this field the most difficult problem for the Christian is to reconcile his allegiance to the person of Christ, by whom he is irrevocablly grasped, with his awareness of God's saving activity beyond the borders of Christendom. Two main paths offer themselves. A way that has often been taken is to give the idea of incarnation an adjectival instead of a substantival interpretation. One can then speak of divine incarnation in varying degrees in the great prophets, saints and seers of all ages. However, I prefer, in chapter 11 , to reformulate the doctrine of the incarnation in its full traditional meaning and then to ask, in chapter 12 , to what logical category this doctrine belongs. I suggest that it is a mythic expression of the experience of salvation through Christ, and as such it is not to be set in opposition to the myths of other religions as if myths were literally true-or-false assertions.

This option involves seeing Jesus as a human being rather than as the Second Person of the Holy Trinity living a human life. Such a view of him coincides with the conclusions of a growing number of New Testament, patristic and theological scholars today, and the realisation that the notion of divine incarnation is a mythological idea of great historical power and importance is now fairly widespread. The recent volume by a group of British theologians, The 
Myth of God Incarnate (edited by myself), illustrates this thesis from a number of different angles.

It is desirable to be clear about what is and what is not at issue here. That Jesus was in his lifetime the lord whom many followed, and that he has ever since been the lord whom great numbers in each generation have followed through the church's scriptural 'memory' of him, is not in question. Jesus' own intense and transforming awareness of God has helped to make God real to millions, bringing them out of the darkness of self-concern into the light of the divine presence. In this way he has been and continues in varying degrees to be the saviour of millions. And the incarnational language adopted by the early church to express Jesus' efficacy as lord and saviour was a very natural language to use in the ancient world. It was also probably virtually inevitable that in the course of time this poetry should have hardened into prose, a metaphorical son of God becoming the metaphysical God the Son, the Second Person of the Holy Trinity. This was of a piece with the literal understanding of the Bible during the same period.

Today however we need, not to abandon the traditional language of christian devotion, but to become aware of its mythological character. For if we continue to construe it literally we shall be continually handicapped in our attempts to come to terms with God's activity towards mankind as a whole. If God has come to meet men personally in Christ, and nowhere else, then men must come to Christ, and nowhere else, to meet him. Again if, as the church, has traditionally taught, it is by Jesus' death, and by this alone, that there is salvation; and by a conscious commitment to Jesus as Saviour, and by this alone, that men may appropriate that salvation, then it follows that all men must be converted to christian discipleship as the only way to God. This is the unavoidable logic of the traditional view of Jesus as uniquely God the Son incarnate. But this takes us straight back to the older and now discredited view of the other world religions as streams of alienated life from which men must be rescued by transference into the Body of Christ, within which alone they can be fully accepted by God. 
xii

Paralled with the discarding of this older view, there has come the discovery that Jesus himself did not claim to be God incarnate. The pre-critical assumption that Jesus walked the earth as a consciously divine being, teaching the view of himself which is attributed to him in the Fourth Gospel, has been abandoned by nearly all New Testament scholars. Those of them-and they are still no doubt the majority-who hold to the traditional interpretation of Jesus, now say instead that the claims that were later made about him were implicit, rather than explicit, in his earthly words and deeds. The most recent epicycle of theory is that Jesus' divine Sonship was enacted and revealed, not in his earthly life, but in his resurrection-so that it is the raised and glorified Christ who is the Second Person of the Trinity.

The implications of this defensive strategy are much more damaging for the traditional position than many of its advocates appear to realise. The idea of incarnation, becoming flesh, must refer to the earthly Jesus, the Jesus of human flesh and blood who walked the hills and villages of Galilee; for otherwise we are no longer talking about incarnation at all. And if this earthly Jesus, who is part of our human history, did not think of himself as God incarnate, then we now have the strange doctrine of a God who did not know that he was God. Far greater than the traditional paradox of God incarnate is the new paradox of God incarnate who does not know that he is God incarnate. This manoeuvre must surely have come to the end of the road in the implied claim that the church knows who Jesus was better than he knew himself; and yet that this same Jesus, who did not know what the church knows about him, was none other than the Second Perosn of the Trinity incarnate!

And so the whole complex of questions concerning the person of Jesus and the nature of Christianity and its place within the universe of faiths has become open and alive in new ways. This book is offered, in this more accessible form, partly as an attempt to grapple with the perennial problems of the philosophy of religion and partly as a stimulus to discussion of these new issues, which have so recently thrust themselves upon us and which are bound to 
remain close to the centre of theological attention for many decades to come.

Department of Theology Birmingham University 


\section{Acknowledgements}

A NUMBER of these chapters are either altered or unaltered versions of essays first published in various journals or books, and I am grateful to the editors and publishers concerned for permission to reproduce them here.

Chapter I, 'Theology's Central Problem', was my inaugural lecture in the $\mathrm{H}$. G. Wood chair of theology, delivered on $3^{1}$ October 1967 , and was first published by the University of Birmingham.

Much of the first half of Chapter 2, 'Religion as Fact-asserting', was a guest editorial in the Princeton journal Theology Today, April I $96 \mathrm{I}$, and is reprinted with the permission of that journal; and much of the second half of the same chapter first appeared as an article in Theology, March 1968.

Chapter 3, 'Religious Faith as Experiencing-as', was a lecture delivered under the auspices of the Royal Institute of Philosophy and first published in Talk of God, edited by G. N. A. Vesey (London: Macmillan and New York: St Martin's Press, I 969).

Chapter 4, 'God, Evil and Mystery', appeared in its original form in Religious Studies, April 1968, in reply to an article by Professor Roland Puccetti of the University of Singapore entitled 'The Loving God - Some Observations on John Hick's Evil and the God of Love' (Religious Studies, April I 967). Chapter 5, 'The Problem of Evil in the First and Last Things', was likewise originally a reply (F.T.S., October 1968) to an article by Dom Illtyd Trethowan of Downside Abbey entitled 'Dr Hick and the Problem of Evil' (7.T.S., October 1967 ), and is reprinted by permission of the editors of the Fournal of Theological Studies.

Chapter 6, 'God as Necessary Being', was first published in The Scottish Fournal of Theology, December ig6r.

Chapter 7, 'The Reconstruction of Christian Belief', appeared as two articles in Theology in 1970 . 
The next three chapters, 8, 9, and Io, on 'The Essence of Christianity', 'The Copernican Revolution in Theology', and 'The New Map of the Universe of Faiths', were delivered as public lectures in Carrs Lane Church Centre, Birmingham, in February and March 1972. I remember with appreciation the high degree of theological interest shown by the Carrs Lane audiences. Part of Chapter 9 subsequently appeared in the Expository Times, November 1972, in a series on Learning from Other Faiths.

Chapter I I, 'Christ and Incarnation', was originally part of an article contributed to Prospect for Theology: Essays in Honour of $H$. H. Farmer, edited by F. G. Healey and published in 1966 by James Nisbet and Co. Ltd. It is now reprinted by permission of these publishers as copyright holders. The next chapter, on 'Incarnation and Mythology', has not appeared before, though part of it was delivered as a paper to the Society for the Study of Theology meeting at Lancaster in April 1973.

The last chapter, 'Towards a Theology of Death', first appeared in Dying, Death and Disposal, edited by Gilbert Cope (London: S.P.C.K., I970), and foreshadows a full-scale work on the theology of death which is now two-thirds written. 


\section{Introduction}

TніS воок reflects both the perennial and the changing character of the problems of religious thought. The starting point is religious language. Here the fundamental question is whether in speaking, for example, about God and eternal life the man of faith is making assertions about 'what there is' and 'how things are'. Is it a question of fact (though not of course physical fact) whether God is real? Or is God-talk a mythological expression of a state of the human mind involving no claims about that which is said to transcend both man and matter? Are the key religious statements true or false, in the sense of corresponding or failing to correspond with reality; or is it more appropriate to ask whether they satisfy or fail to satisfy us emotionally? I am sure that a great deal of the language of faith is variously emotive, poetic and mythic rather than fact-asserting, but I nevertheless want to insist that the core religious statements are true or false in a sense that is ultimately factual. ${ }^{1}$ This leads in Chapter 2 to a criticism of non-cognitivist analyses of religious language, including the currently influential but in my view misleading Wittgensteinian language-game theory.

An insistence upon the basically cognitive character of religious discourse carries with it an obligation to face four major contemporary challenges to religious belief - first, the non-coerciveness of theism in view of the fact that every aspect of our experience, including the religious aspect, is capable of naturalistic explanation; second, the ancient and grisly problem of evil; third,

1 Another paper closely relevant to this issue, which I considered including, is 'Theology and Verification' (Theology Today, April r96o). But this essay has been reprinted in a number of collections and is readily available - most accessibly, in paperback form, in The Existence of God, edited by John Hick (New York: The Macmillan Company, and London: CollierMacmillan, 1964), and The Philosophy of Religion, edited by Basil Mitchell (London: Oxford University Press, I97I). 
the question of the internal consistency of the concept of God; and fourth, the problem of the conflicting truth-claims of the different religions. The rest of the book deals, at varying lengths, with these four great issues.

In response to the first of them, the challenge of the noncoercive and apparently optional character of theistic belief, Chapter 3 presents a theory of faith as the interpretative element within religious experience, continuous in character with the element of interpretation in all our experience. The need for this voluntary act of interpretation preserves our status as free beings over against the infinite divine reality. The first half of Chapter 7 , on the relation between the scientific and religious understandings of the world, is also concerned with this issue.

The next two chapters are a response to the theological problem of evil, and present a contemporary version of the Irenaean theodicy in relation both to human pain and suffering (Chapter 4) and human wickedness (Chapter 5). The last chapter of the book, on immortality, is also directly relevant to the mystery of evil, for I believe that any genuinely christian grappling with this problem has to take seriously the idea of a life to come.

Chapter 6, on the idea of necessary being, is a partial attempt to meet the third challenge, concerning the viability of the concept of God.

With the second half of Chapter 7 we approach the immense new problem that has been looming ever larger on the horizon of religious thought as the adherents of each of the world faiths have become more clearly aware of the spiritual reality of the other faiths. From my own point of view these chapters represent a fairly considerable process of rethinking in response to new experiences. The whole subject of the relation between Christianity and other religions is one which I had, in effect, largely ignored until coming to live in the multi-cultural, multi-coloured and multi-faith city of Birmingham, and being drawn into some of the practical problems of religious pluralism. I now no longer find it possible to proceed as a christian theologian as though Christianity were the only religion in the world. Surely our thinking must be undertaken, in the 'one world' of today and tomorrow, on a more open and global basis. Accordingly Chapters 8, 9 and io seek to develop a christian theology of religions which takes the decisive step from what I call a Ptolemaic (i.e. 
one's-own-religion centred) to a Copernican (i.e. a God-centred) view of the religious life of mankind.

In this field the most difficult problem for the Christian is to reconcile his allegiance to the person of Christ, by whom he is irrevocably grasped, with his awareness of God's saving activity outside the borders of Christianity. Two main paths offer themselves at this point. A way that has often been taken is to give the idea of incarnation an adjectival instead of a substantival interpretation. One can then speak of divine incarnation in varying degrees in the great prophets, saints and seers of all ages. However I prefer, in Chapter II, to reformulate the doctrine of the Incarnation in its full traditional meaning and then to ask, in Chapter 12, to what logical category the doctrine belongs. I suggest that it is a mythic expression of the experience of salvation through Christ; and as such it is not to be set in opposition to the myths of other faiths as if myths were literally true-or-false assertions.

The extent of the rethinking involved in coming to this conclusion is measured by the difference between Chapter I I (published in 1960) and Chapter I 2 (first published now). And yet it will I think be seen that this rethinking represents an expansion rather than a reversal of viewpoint. The earlier paper was an attempt to restate the content of the traditional christian teaching. The new paper raises the meta-question whether this teaching constitutes a theological theory or whether it represents, on the contrary, a mythological use of language.

To identify the language of incarnation as mythological in turn involves an expanded awareness of the varieties of religious language. Whilst insisting upon the cognitive, truth-claiming nature of the core of religious discourse it also seems to me important to recognise that much of the language that revolves around this core has mythological rather than literal meaning.

The last chapter, on death and immortality, returns to the insistence upon the factual core of religion and presents man's survival of bodily death as an actual future experience of which we should take account now, both for our living and for our thinking. 